\title{
Broken marriage in aristocratic societies in Edith Wharton's selected novels
}

\author{
Elaheh Soofastaei ${ }^{*}$, Sayyed Ali Mirenayat \\ Faculty of Modern Languages and Communication Universiti Putra Malaysia \\ *E-mail address: ela.soofastaei@yahoo.com, ali.mirenayat@yahoo.com
}

\begin{abstract}
Family is a bridge between individual and society. In my paper, I will survey broken marriage and individual dissatisfaction in two novels by Edith Wharton. The novels in question are The House of Mirth (1905) and The Age of Innocence (1920). Edith Wharton portrays her concern by the conflict between the individuals and the social groups which they live in there. Her treatment of the family is always in association with the bourgeois society, with the ambitious stock brokers from the west. This conflict can be seen in their attitudes to love, marriage, divorce, and remarriage. In the novels, Marriage, as an indissoluble matter and even an invariable failure, is main concept and sex outside marriage is meaningless. Wharton shows divorce in aristocratic societies in an old-fashioned lifestyle.
\end{abstract}

Keywords: divorce; broken marriage; individual dissatisfaction; bourgeois; aristocratic societies

\section{INTRODUCTION}

In the early of twentieth century, for men in the bourgeois families, sex was divorced from feelings of tenderness, and women were looking for upper-class men, and as we know the major problem in this time was the economic situation of women in aristocratic U.S. society. Women in this time were forced to make themselves beautiful and dutifully attractive to marry a well-to-do man or they confronted with poverty or dependency. Marriage entailed a conflict between the parents and children. While the parents had their eyes on wealth, the adolescents were filled with romantic love. Children grew up in an atmosphere charged with emotional conflicts. Remarriage is the traditional answer to most of the divorced men and women who face many problems of single parents. It is a relief from unbearable loneliness. Where families have a strong bond with the community, divorces are rare. The social welfare scheme provided to single parents has increased the divorce rate. There are many other reasons like mismatch in age, race, religion, education and income behind divorces besides emotional incompatibility. The problem area in remarriage is the relation between the children and the stepparent and stepbrothers or stepsisters.

Family has been an important role in social structure and shaping the destiny of human beings and it has been studying by many literature scholars. Scholars have found it difficult to define it, as it means different things to different races. Nevertheless, sociologists and theorists of family have evolved categories to describe it. The alarming growth-rate in divorce and decline in interest in marriage especially in America, have been a cause of concern among 
family theorists like Mark Poster, A.J. Cherlin, and some theorists like them. These theorists of the family draw upon psychology, sociology and economics for their theories. There are indeed disciplines like religion, politics, law and feminism which also attempt to construct theories of family.

Surprisingly romantic love is often based on misunderstanding rather than understanding in the novels of Edith Wharton. Romantic love is based largely on physical attraction and when the men and women come closer and see the real character of their partner they are disillusioned. In her novels, of course, she presents different attitudes to marriage. Whatever be the attitude to marriage, in the world of Wharton, marriage was invariably a failure. The failures in marriage depicted by her are not only realistic but also in tune with her own experience. Edith Wharton was against divorce, though she herself divorced her husband.

\section{THE HOUSE OF MIRTH: A PIPEDREAM OF ARISTOCRATIC LIFE}

Edith Wharton represents the value of the family as an institution along with its problems in her novels. The House of Mirth shows that how the heroine's character, Lily Bart, and the psychic structure of the family along with her association with the upper class families ruins her life and drives her to suicide. The novel portrays well-bred women like Lily who are taught to be attractive and charming enough to trap wealthy men in order to make their future more beautiful with their money. A hypocritical society which old manners and morals are getting disappears and increasingly replaced by money and visible consumption to show off their properties.

At the beginning, Lily seems to be part of an extravagant modern family, but as the story goes on, the reader will figure out that she is not quite corrupted as she seems. Some Old New York values are still worthwhile for her such as loyalty, chastity, discretion and above all, dignity. The mind and character of Lily can be easily uncovered in her bringing up in a bourgeois family. She was herself because of the way she was taught by her parents.

"Sons and daughters of bourgeois families learned that the fulfillment of all wishes depends in reality on money and position" (Poster, 55).

Lily was trained for being happy and free from worries is having money. She thought that the best way for climbing the social ladder and becoming a member of upper class is to marry with an upper class man. Her mother tried her best to see this especially after death of her father but died without seeing that.

Cherlin like Poster emphasizes the relationship between marriage, economy and emotional well-being of a person. For women who brought up in bourgeois societies without any economic independence, marriage had been given economic stability in the early twentieth century. There also were fewer restrictions for married women, so they enjoyed from greater social freedom than unmarried ones. For instance, when an unmarried lady visited a man in his apartment, she was considered as an indiscreet, just like Lily's visiting to Selden's apartment. Lily made herself beauty, attractive and intelligent in order to find a suitable life-partner. She knew that these items were not adequate and mental gifts were necessary for a lucky marriage. 
"I have the reputation of being on the hunt for a rich husband", Lily said to her friend and hostess Judy Trenor" (40).

She had got a dream of marrying an Italian Prince with a castle in the Apennines; or English aristocratic with a political aspirations. Although she was not looking for having a marriage of convenience but she tended to higher things in life. There is a paradox in her fate that she did not wish to have money alone; but she could not live a minute without it. She rejected one or two offers of marriage in her life only because she will have a broken marriage without considering any other important things in her married life. Lily had two different characteristics in making up her mind for marriage. First, she looked at upper class people and a luxurious living regardless the meaning of real life, so it forced her to marry a rich man. Second, her pure and sensitive mood compelled her to reject offers and proposals from rich but primitive people like Sim Rosedale or Trenor, and she went on her friendship with a poor Lawrence Selden an educated and bright lawyer.

\section{THE AGE OF INNOCENCE}

\section{Lack of Cultural Relativity in Aristocratic Societies}

The Age of Innocence enacts the conflict between the individual and the society. A Pulitzer Prize winner novel in which reveal the importance of aristocracy in people's personal and social life in Old New York in late $19^{\text {th }}$ century. Old New York of the 1870 s is an unsophisticated society with narrow-minded people who decry and condemn getting divorce for over thirty years. The Age of Innocence is a study of aristocratic families of the 1870s, which Edith Wharton calls it the leisure class. The relationships between husband and wife were largely stable. In that time if a married woman had extra-marital relations, people would have been frowned upon with spoken behind her. Not only divorces were rare but also wives were honored by the husbands. Home was considered the best place for women where they knitted, received calls and visited friends and relatives. Education also was offered for both sons and daughters at home. The facts of life were unknown to young women until the time of marriage. These facts were not generally discussed and anybody disobey them, the punishment was ostracized. In fact, the standards were accepted by people without any reason.

A novel about two families of aristocratic and bourgeois which refer to the move of the characters from former to latter and it is quite obvious in the hero of this novel, Newland Archer. The most important thing for him was individual freedom. Archer believed to equal freedom right for women. The authority on family, Mr. Jackson imply that Countess Olenska was seen living with her husband's secretary who helped her to escape from Count Olenski. She was going to separate from her European husband. Although, divorce was common in Europe but it was not in America. Archer convinced her against it: "Our legislation favors divorce-our social customs don't" (109). Newland's reply was also typical: "living together? Well, why not? Who had the right to make her life over if she hadn't? I'm sick of the hypocrisy that bury alive a woman of her age if her husband prefers to live with harlots". $\mathrm{He}$ stopped and made himself calm then lit his cigar and continued "Women ought to be free - as free as we are". (39) 
Towards the end of novel, Dallas (Newland's son) criticized the family life of his father and May about thirty years after Newland's marriage. He pointed out the negative side of their family life:
"No, I forgot. You never did ask each other anything, did you? And you never told each other anything. You just sat and watched each other, and guessed at what was going on underneath. A deaf-an-dumb asylum in fact! Well, I back your generation for knowing more about each other's private thoughts than we ever have time to find out about our own" (359-360).

Cultural relativity as a principle does not mean that one nation should accept and behave like another nation. But, on the contrast, it means that positives and negatives aspects of each nation are evaluated with similarities. In the novel, when Countess Olenska as a divorced woman lived in Europe with an attitude in which divorce was commonplace, but when she traveled to the United States, she confronted with a different attitude in which divorce was unsolvable. People, in there, decried getting divorce. Then, this issue could originate from lack of cultural relativity. According to Martin Scorsese (1993), the title of The Age of Innocence can be read as a euphemism for The Age of Hypocrisy where the author describes the style of living of the people of the Old New York in 1870s. It is all about the people's attitude to and experience of marriage. It also could be originated from a sort of cultural relativity in which Edith Wharton used an unrelated word in the title of her novel.

Although, this novel reveals the failure of Ellen-Newland relationship but as a matter of fact is the romantic story outside marriage. The only love that had happened between May and Newland was an ordinary duty between every couple and no more. The early married life of Newland and May was unpleasant for both. May had serious doubts about his honesty so she examined Newland with questions which irritated him. He had been forced to tell lie and had a bad feeling about it. He wanted to be honest but thinking about Olenska made it difficult and impossible although it was an illegal affair and Old New York society was object to it.

Critics usually examine the novels from a literary or humanistic point of view. Mark Poster generates four models of family structures and develops categories of family structure, which are used in the analysis of the novels chosen for study. Poster's significance consists in constructing a theory of the family which is broad, flexible, critical and non-ideological (1978). According to Poster, the Oedipus complex by Freud was not the problem of the child but that of the parents. The parents in the Victorian bourgeois society enjoyed a privacy and individualism which was a double-edged sword. Marx and Engels declare that the subjugation of woman to man was another tragic fall-out of capitalism, and Poster argues that the Marxist theory of family should be freed from the prison of economic determinism (66-68).

\section{CONCLUSION}

Edith Wharton's character point out that she is covertly an idealist, and in most cases tries to damage intentionally her own attempts at marrying money. But as a matter of fact, in most of her books she does not openly go against the system. In the time of Edith Wharton, divorced or separated people were looked as anathemas and society considered this behavior as a degradation, but divorce was legally permitted. The growing number of broken marriage, the high divorce rate, and the emergence of co-habitation as a substitute-marriage, etc. are 
common concerns of sociologist, family theorists and psychologists. Edith Wharton, as well, had the same concerns about divorce and its situation in society.

The family as an institution has changed considerably, requiring a redefinition. It has faced threats to its basic structure from economic, social, psychological and political changes, which are inevitable. A few conclusions can be drawn from these statements. Firstly, getting and looking at divorce was more common in Europe than America or at least, legally, it was approved in there. Secondly, tendency for divorce were progressive in America due to the enlightenment ideas and individualism but in Europe, attitudes were different. However, it had an unpleasant result on married life of May and Archer. These differences could be strongly named cultural relativity.

\section{References}

[1] Ammons, Elizabeth. Edith Wharton's Argument with America. Athens: The University of Georgia Press, 1980.

[2] Bauer, Dale M. Edith Wharton's Brave New Politics. Wisconsin: The University of Wisconsin Press, 1994.

[3] Bell, Millicent. ed. The Cambridge Companion to Edith Wharton: New York: Cambridge University Press, 1995.

[4] Ed. Kingsley Davis. New York: Russell Sage Foundation, 1985, 397-414.

[5] Lindberg, Gary. Edith Wharton and the Novel of Manners. Charlottesville: University Press of Virginia, 1975.

[6] Peden, Joseph R. and Fred R. Glahe. "Introduction: The American Family in a Free Society".

[7] Poster, Mark. Critical Theory of the Family. New York: The Seabury Press, 1978.

[8] Wershoven, Carol. The Female Intruder in the Novels of Edith Wharton. Rutherford, N.J.: Fairleigh Dickinson University Press, 1982.

[9] Online Resources: Scorsese, Martin. (1993). "The Age of Innocence". Retrieved from http://www.thefreelibrary.com/The+Age+of+Innocence\%3a+Martin+Scorsese $\% 2 c+1993$ -a0112720631 